\title{
Trips of Death and Alienation in Beckett's All That Fall
}

\author{
Mustafa Ahmad Mohammed* \\ Department of English and Literature, Faculty of Arts, Isra University, Amman, Jordan
}

Corresponding Author: Mustafa Ahmad Mohammed, E-mail: Samaray48@Gmail.com

\begin{tabular}{l} 
ARTICLE INFO \\
\hline Article history \\
Received: June 08,2017 \\
Accepted: August 12,2017 \\
Published: December 01, 2017 \\
Volume: 6 Issue: 7 \\
Special Issue on Language \& Literature \\
Advance access: September 2017 \\
\hline
\end{tabular}

Conflicts of interest: None

Funding: None

\begin{abstract}
Samuel Beckett, besides writing for the stage, has during his long career written for both radio and TV. He has also written one script entitled Film which was filmed for the New York Film Festival in 1956. All That Fall was written in 1956 and it is the longest Radio play of Beckett. Suffering, a fundamental attribute of existence, constitutes the centre of Beckett's plays and the plays demonstrate, in turn, different kind or human responses to suffering. Maddy's deep sorrow and anguish at the loss of her daughter Minnie arouses her desire for an end, what she calls to be" in atoms". Dan, Like Hamm, overcomes the Absurd by exiling himself to suffering and refusing to be intimidated or beguiled. Unlike Hamm's insistent attempts to exterminate all life, Dan understands the futility of such effort and restrains himself from giving in to that kind of impulse. But the irony is that death is all around him underscoring the fact that death and alienation are no solution to the problems of life.
\end{abstract}

Key words: Trips, Death, Loneliness, Absurd, Alienation

\section{INTRODUCTION}

All That Fall evokes a grotesque vision compounded of metaphysical fear of an annihilating force, the horror of loneliness and the sense of alienation from the inexorable working of the universe. In all his plays, Beckett incorporates the theme of a hostile mechanism reducing human existence to nothing and presents a frightening perception of the ceaseless manner in which life continues through the cycle of birth and death.

To Beckett, human existence is pathetic because it is inseparable from pain and misery and is lacking coherence. Hence with an almost missionary zeal, Beckett claims for the artist the responsibility of finding a suitable form to express human misery in its entirety. In his works he has proved faithful to his intention by innovating a new form of drama to accommodate what he terms" the mess" or" the confusion"(Tom F. Driver, 1961, p.22-23.) Beckett is not obsessed merely with thoughts of death, reducing life to inanity, but he is concerned with the plight of Man caught in an eternal cycle of birth and death with longing for escape and freedom from confinement within the finite universe. The decanting process from existence to non-existence is cyclic. Beckett presents his characters engulfed by Time as they passively wait for a release from this imprisonment. But there is no hope. They are trapped; to live is to submit oneself to the Absurd, but so is to die. Thus Beckett's awareness of absurdity is two- fold: it sees life's movement towards death that reduces everything into nothing, to be followed by renewed movements towards the emptiness of life that will re-start the absurd cycle once again.
In 1956 the BBC commissioned Samuel Beckett to write a play for radio production. At the beginning Beckett hesitated to do so. In one of his letters to his friend Nancy Cunard date July 1956 he wrote, "Saw Barry of BBC TV who is interested in the mime (and why not?) and am told Gieluld wants a play for $3^{\text {rd }}$.programme. Never thought about Radio play technique but in the dead of t'other night got a nice gruesome idea full of cartwheels and dragging of feet and puffing and panting which may or may not lead to something."(Ackerely \&Gontarski, 2004, p.27) In fact, in All That Fall Beckett returned back to English, and the play has Irish characters and the events are taking place in familiar Irish landscape. Ronan McDonald thinks that All That Fall shows "a relatively high level of overt Irishness and autobiography. Boghill is clearly based on Foxrock, the affluent commuter village outside Dublin where Beckett was brought up"(McDonald, 2006, p.53)

All That Fall, the first of his radio plays, is different from the other plays in matter of length and theme. While the shorter pieces like Rough for Radio I and Rough for Radio II are able to resurrect an image, this play tells a story of human relationship between a man and his wife. In All That Fall the main characters are Dan Rooney and his wife Maddy. Dan is once again an old, blind and lonely man. He looks like Pozzo, Hamm and Henry and shares with them their Sadomasochistic behavior, agedness, and sightlessness. Dan Rooney is in the physical sense, an outsider, cut off from the world social activity. Throughout the play we notice that Dan is cynically bitter and dried of all positive emotions towards his wife. Maddy is a woman in her seventies and she 
is suffering from obesity. Dan says that she weights two hundred pounds. Her heavy weight almost immobilizes her and she keeps "dragging" her feet in her trip to Boghill station to meet her husband. Beckett repeated the word "dragging" nine times in the first three pages of the play to emphasize her immobility. She is weary and broken hearted because of age and obesity. Besides she keeps lamenting the loss of her daughter Minnie. She finds herself imprisoned in her obesity and so she seeks any sort of freedom:

How can I go on, I cannot. Oh let me just flop down flat on the road like a big fat jelly out of a bowl and never move again! A great big slop thick with grit and dust and flies, they would have to scoop me up with a shovel. (Beckett, 1986, p.174)

In contrast to Dan, Maddy does not have the lasting strength to remain an exile, in vacuum, unsustained by hope and faith in human warmth, kindness and companionship. Maddy is no way less insensitive than Dan to the decay and disintegration all around her. In fact, she is the focal point from which we discern the extent of the decay. She herself, "Oh I am just a hysterical old hag...destroyed with sorrow and pining and gentility and church-going and fat and rheumatism and childlessness."(Beckett, 1968, p.174) traverses different stages on her way to meet Dan at the station. She is wary and broken hearted both from age and disease and from the loss of her little Minnie nearly forty years back.

In All That Fall and Embers Beckett probes the negative emotions of suffering and boredom of human relationships. The Dan-Maddy relationship is a sadomasochistic like those Henry and Ada of Embers. Through Henry's voice we are witness to three Henrys- Henry of the past, Henry at the present and Henry in the future. In his reminiscence of his past, he reveals his three refold-relationships with his father, wife and daughter and his failure in every one of his roles at every stage of his life. As the play opens, he sits alone on the seashore, "an old man, blind and foolish"(Beckett, 1986, p.253) feeling less secure and more lonely like Dan. Henry had got entangled in life through his marriage with Ada that had proved a misery. Ada was more concerned with appearances rather than reality. With her, love and sex become mockeries, vulgar, obscene rituals to be gone through. She had protested against Henry's passionate advances at a very early period of their married life. Unlike Maddy who keeps looking for "Love that is all I asked a little love "(Beckett, 1986, p.174) Ada had been conscious only of genteel conventionality that drained away all spontaneity from her life. She restricted Henry from a full participation in life with her repeated "Thou Shall Nots". Henry recalls her constant injunctions to him like "Don't stand there thinking about it"(Beckett, 1986, p.259)"Don't wet you good boots"(Beckett,1986.p.259)" Don't stand there gaping"(Beckett,1986,p.260.) There was no meeting ground between the two. Ada could not sympathies with Henry's inertness and weariness with life. She felt nothing but disgust and despair over his refusal to immerse in life as she conceived of it. In All that Fall and Embers Beckett shows that both the aggressor and the victims are suffering. They are sadomasochistic characters who enjoy master-slave relationships. They are tied to their oppressors who would inflict pain and cruelty on them. All That Fall evokes a grotesque vision compounded of metaphysical fear of an annihilating force, the horror of loneliness and the sense of alienation from the inexorable working of the universe. In all his plays, Beckett incorporates the theme of a hostile mechanism reducing human existence to nothing and presents a frightening perception of the ceaseless manner in which life continues through the cycle of birth and death. To Beckett, human existence is pathetic because it is inseparable from pain and misery and is lacking coherence. Beckett is not obsessed merely with thoughts of death, reducing life to inanity, but he is concerned with the plight of Man caught in an eternal cycle of birth and death with longing for escape and freedom from confinement within the finite universe. The decanting process from existence to non-existence is cyclic. Beckett presents his characters engulfed by Time as they passively wait for a release from this imprisonment. But there is no hope. They are trapped; to live is to submit oneself to the Absurd, but so is to die. Thus Beckett's awareness of absurdity is two- fold: it sees life's movement towards death that reduces everything into nothing, to be followed by renewed movements towards the emptiness of life that will re-start the absurd cycle once again. The trips of the Maddy and Dan are the main symbols of Man's trip from birth to death.

\section{MADDY'S TRIP}

In All That Fall Beckett's focuses on Maddy's trip to Boghill railway station to meet her blind husband and walk him home. She meets him off the train on which he commutes daily from his "silent, backstreet, basement office, with its obliterated plate, rest-couch and velvet hangings, and what it means to be buried there alive, if only from ten to five"(Beckett,1986,pp.193-194) It seems that she wanted to surprise him on his birthday. She tells Mr. Tyler to inform Dan that she was on her" way to meet him when it all came over me again, like a flood. Say to him, Your poor wife, She told me to tell you it all came flooding over her again and...[The voice breaks]...she simply went back home... straight back home..."(Beckett,1986,p.176) On the way to the railway station, she meets different variety of characters that are all in a bad shape. They include Tyler cursing the wet Saturday afternoon "what sky! What light!"(Beckett, 1986, 175.) the stiff Slocum" gazing straight before me, Mrs. Ronney, through the windscreen into the void" (Beckett,1986,p.178) and the ageless Miss Fitt, " a bag of bones "(Beckett,1986,p.184), dark and farthest from being fit, and Mr. Barrell, the station-master, well on his way out like his "ferrety purple -faced, testy and snappy father... to grow his own roses."(Beckett, 1986, p.181) The majority of the Beckettians are uniformly worn out with age and ailment, paralyzed and immobilized, and awaiting a slow, uncertain extinction as a possible relief from their languid, weary existence. They are like Beckett whose life shows "history of illness including poor eyesight, weak lungs, panic attacks, racing heart, various types of cysts and skin eruptions."(Ben-Zvi, 2011,p. 691)

Maddy's sadness is reflected in her reaction to the faint music of Schubert's Death and the Maiden played continu- 
ously by the poor, old and lonely woman "all alone in that ruinous old house". (Beckett, 1986, p.172) Maddy knew that it is useless to stay at home alone and plays sad music. In fact, loneliness is the sole companion of Maddy in her trip. She says, "It is suicide to be abroad. But what it is to be at home...What it is to be at home? "(Beckett, 1986, p.175)

She vents against being entrapped by obesity, pain and loneliness. She sums up her understanding of her hopeless condition and cries, "Christ, what a planet!"(Beckett, 1986, p.183) But Maddy hates to stay alone in this merciless inhuman situation. She tries to overcome the absurdity of her cold existence by searching for sympathy and comfort through her relationship with other fellow travelers. But all her efforts to create contact with each one of her follow journeyers to Boghill station went in vain. They are unable to understand her or sympathize with her especially after the loss of her daughter Minnie. Each one of them is engulfed with his own miseries and worries. Two of these characters tried to give Maddy physical assistance on her way to the train station. Both Tyler and Slocum regret having stopped and not "shot by her without a word."(Beckett, 1986, p.175) Maddy shouts at Tyler, "Can't you see I am in trouble?[With anger.] Have you no respect for misery?(Sobbing.) Minnie! Little Minnie!(Beckett,1986,p.176) The phenomenon of death is introduced through Minnie and the little child who feel under the wheels. But paradoxically, death strikes only the young and innocent sparing the aged and the withered beings. The phenomenon of death has been linked to Jung's lecture on the death of young girl. Jung" spoke of a little girl and the words he used about her stayed with Beckett and affected him deeply."(Campbell, 2005, p.164)Campbell says that" Beckett recall these words in All That Fall, where he has Mrs. Rooney remember the lecture by Jung, as if she had been present".(Campbell,2005,p.164) All the characters in the play are in a terrible state of decay experiencing "A lingering dissolution"(Beckett, 1986, p.175) Dan is blind and unsteady of his limbs. All his life he has experienced nothing but sickness. He tells his wife in a matter of fact tone:'Did you ever know me to be well? The day you met me I should have been in bed. The day you proposed to me the doctors gave me up"(Beckett, 1986, pp191-192)

Love, compassion and friendship have left Maddy's world. She is all alone and alienated from her fellow travelers. She tried to communicate with the Station master Mr.Barrel, but he did not pay much attention to her and left her alone. In a moment of realization Maddy understands how cruel human beings are to each other:

I estrange them all. They come towards me, uninvited, bygones, bygones, full of kindness, anxious to help...genuinely pleased...to see me again ...looking so well...A few simple words... from my heart .... and I'm all alone...once more...I should not be out at all! I should never leave the grounds!(Beckett,1986,p.182)

Maddy is unable to see any meaning in actions and relationships or she has the feeling that life has no purpose. Thus she remains alienated from her fellow being. However she continues her trip to Boghill railway station to meet her blind, ill, and taciturn husband. Vivian Mercier thinks that:
Maddy is an example from truly dog-like devotion. Having only just recovered from a long illness, she struggles in infinite discomfort as far as the railway station to give her husband a surprise for birthday by meeting his train she suffers intense anxiety because the train is fifteen minutes late, but when the blind Mr. Rooney arrives, he is far from pleased by her surprise. (Mercier,1979, p.218)

With Dan Rooney, Beckett achieves a hat-trick of blind dramatic heroes, cynically bitter and dried of all positive fellow feelings. Like Pozzo and Hamm, Dan has also his menial, this time in his wife, Maddy on whom he can vent his anger and frustration with life. The Dan-Maddy relationship is sadomasochistic like those of Pozzo-Lucky and HammClov pairs, where the aggressor and the victim, both suffering, are indissolubly linked. Dan, belonging to Hamm-Clov lineage, exiles himself to suffering and from his very first appearance till the end, never gives up either his insight into Man's real condition or his protest against such a condition. Nor does he take refuge in illusory hopes, but systematically negates each illusion. Unlike his wife, Maddy, he stays clear of all human contacts except the barest necessary, least such contiguity should instill a false sense of security and comfort in him as against his clear vision of a miserable and hopeless existence. He is severe on Maddy who looks to him for a bit of love and comfort to sustain her through a painful and grievous existence. Dan derives a sadistic pleasure in denying Maddy the little love that she asks for:

Love, that is all I asked, al little love, daily, twice daily,fifty years of twice daily love... A peck on the jaw at morning, near the ear, and another at the evening,peck,peck, till you grow whiskers on you.(Beckett,1986,p.174)

Dan refuses to oblige her with a kiss after she had dragged herself to the station to meet him and lead him home on his birthday. Dan feels outraged and reproves her:'Kiss you? In public ? On the platform? Before the boy? Have you taken leave of your senses?"(Beckett, 1986, p.188) In the face of savage unpredictability of existence, Dan has resolutely denied himself all natural human urges and responses. His tendency towards masochisms is evident in his self denial of any kind of closeness with fellow beings. His coldness compounded of lovelessness and harshness is deliberate and calculated a bitter response to life that is subjected to metaphysical cruelty and arbitrariness. Throughout his life he has been "buried alive, if only from ten to five, with convenient to the one hand a bottle of light pale ale and to the other a long ice- cold fillet of hake. Nothing, I said, not even fully certified death, can ever take the place of that."(Beckett, 1986, p.194)But being at home is no better." There are the horrors of home life, the dusting, sweeping, airing, scrubbing,waxing, waning,washing... and slamming"(Beckett,1986,p.193) The only course left to for Dan is to do nothing, to " Sit at home on the remnants of my bottom counting the hours- till the next meal."(Beckett, 1986, p.190) Dan enjoys mental calculations, counting the number of steps at the station or counting the pennies saved and the pennies spent or tracing the etymology of words in accordance with Grimm's law- in short, he prefers the world of abstractions to the world of reality and its immediate experience. "I have 
been up and down these steps five thousand times and still I don't know how many there are. When I think there are six there are four or five or seven or eight and when I remember they are five they are three or four or six or seven and when finally I realize there are seven there are five or six or eight or nine.'(Beckett, 1986, p.189)

Perhaps Dan's coldness and lovelessness is the main reason for interpreting that Maddy had sex with Mr.Slocum on her way to Bogshill station. Alpaugh believes that" Beckett taking the advantage of his form, arranges the dialogue to suggest, by accumulation of ambiguous phrases, that Slocum and Rooney are attempting intercourse."(Alpaugh, 1966, p.326) In fact Mr. Slocum stops to give Mrs. Rooney a lift to the station but the dialogue may insinuate such action between Mrs. Rooney and her old admirer:

Mrs. Rooney. Oh!...Lower!...Don't be afraid!...We're past the age when...There!...Now!...Get your shoulder under it...Oh!...(Giggles.) Oh glory!...Up !Up!...Ah! I'm in!... (Beckett,1986,p.178)

Maddy is the embodiment of sexually repressed woman. But Dan belongs to Pozzo-Hamm lineage in sporting a cruel loveless exterior. Like Hamm he is harsh and severe on his dependent, Maddy, in his attempt to school her into acceptance of the inhuman reality of existence. While Hamm clowns his way to cruelty, Dan, despite his apparent calm, appears to be a grotesque figure displaying psychological abnormality. His refusal to extend his personality and respond to love and other human emotions indicates his awareness of the basic loneliness of man and of the cold reality of all human experiences in the context of the Absurd. One is reminded of Sherwood Anderson's grotesque figures showing symptoms of misogyny, frigidity and homicidal tendency. But Dan's grotesque outlook is to be seen against his background of cosmic pointlessness and meaninglessness of existence. All his negative qualities of lovelessness and deliberate withdrawal are to be taken as his protest against the inescapable malady of human degradation and indignity suffered at the hands of metaphysical power.

\section{DAN'S TRIP}

Unlike Maddy's trip to Boghill station, Dan's trip lacks a lot of details. We know that Dan is returning from work on his birthday and the train is fifteen minutes late. After train's arrival, Dan and his wife work their tortuous way home. When Maddy asks him why the train was late, Dan refuses to discuss the fifteen -minute stop claiming that he has no idea why the train stopped. In the closing minute of the play, Jerry, a small boy, overtakes the Rooneys. He has been sent by the station-master to return a mysterious ball which Dan left behind at the station. Maddy asks why the train was late and Jerry Explains:

JERRY: It was a little child, Ma'am. (Mr. Rooney groans)

MRS ROONEY: What do you mean, it was a little child?

JERRY: It was a little child fell out of the carriage, Ma'am[Pause.] on the line, Ma'am.[Pause] Under the wheels, Ma'am.(Beckett,1986,p.199)

All That Fall reveals Dan's defiance of despotism and capriciousness of the Absurd, its arbitrary dispensation of de- cay and death to human beings. For the first time, Beckett's introduces the phenomenon of death directly in the play. All the old men and women are in a terrible state of decay. They symbolize the inextricable imprisonment of man in the vast expanse on the universe, where he ceaselessly strives to live with the misery of being a mortal, to endure what cannot be cured. "Use your head, can't you, use your head, you're on earth, there's no cure for that"(Beckett, 1986, p.108) is Hamm's crushing answer to agony and alienation.

In some research papers Dan has been blamed for the death of the child."Thomas F.Van Laan thinks that "the little child has fallen from the train under the wheels and the strong suggestion, which never made fully definite, that Dan Rooney has murdered the child"(Van Laan, 1985, p.39) While circumstantial evidence might seem to suggest such a possibility, a close following of the text of Dan's halting version of the train incident to Maddy shows that he could not have had a hand in the fall of the child. It is true that Dan always had a desire "to nip some young doom in the bud."(Beckett, 1986, P.191) He confesses to his wife, "Many a time at night, in winter, on the black road home, I nearly attacked the boy.[Pause] Poor Jerry!(Pause) What restrained me then?(Pause) Not fear of man"(Beckett,1986,p.191)

Dan's confession to restraint of his homicidal instincts rises up the issue as to why he would not have imposed a similar restraint at the time of the child's fall. In a rhetorical performance, reminiscent of Hamm, he narrates his return journey to his wife. To begin with he says that he had the compartment all to himself, as usual. At least he hoped so, for he made no attempt to restrain himself. Obviously, there was no need to make any such attempts as he was alone." Alone in the compartment my mind began to work".(Beckett,1986,p. 193) Explaining to Maddy all his thoughts about business and retirement, he comes to the point in his journey when he noticed that the train had come to stand still. Continuing his narration, he proceeds thus:

I concluded naturally that we had entered a station and would soon be on our way again, and I sat on, without misgiving. Not a sound. Things are very dull today, I said, nobody getting down, nobody getting on. Then as time flew by and nothing happened I realized my error. We had not entered a station...I did not care what was amiss. No, I just sat on, saying, If this train were never to move again I should not greatly mind. Then(my italics) gradually a- how shall I say- a growing desire to-er-you know-welled up within me. Nervous probably. In fact now I am sure. You know, the feeling of being confined.(Beckett,1986,pp.194-195)

It is obvious from the above version that Dan's desire to nip some young doom in the bud had welled within him only after the train had come to a stands still, presumably after the fall of the child. There is no clue to the effect that the child had been in Dan's compartment. The desire to put an end to creation, which Dan confesses, had been due to a nervous tension of being confined. If he had exercised restraint earlier with regard to Jerry, that had been due to his perception of the futility of putting a stop to life. It is as absurd a task as that of Sisyphus in trying to roll the boulder up the slop only to see it roll down. The birthday of Dan had proved to be the 
death day of the little child. The arbitrariness and swiftness with which death strikes the young and the helpless, shake him to his core. He realizes that he need not precipitate death in order to wreck his vengeance on the Absurd for its cruel jokes on humanity.

The song of Death and the Maiden brings tears to Dan's eyes, and to Maddy's insistent questioning as to whether he was crying, his answer is one of savage acknowledgement. The tears are tears of impotent anger and a confession of his helplessness to combat metaphysical injustice. To Dan, death does not ring out existence; it merely marks one stage in a series of temporal sequences. So long existence is, there shall be fall; so long there is fall, there shall be a renewal of existence. If lovely laburnums lose their tassels the previous evening, they are in full bloom the next morning. But everything falls and there is no one to uphold them. Hence Dan's reluctance to give unto his homicidal impulses. Dan alone has understood the significance of All That Fall and initiates Maddy into the thought that there is no one to uphold and raise those that bowed down.

\section{CONCLUSION}

All That Fall is concerned with barrenness of life as evidenced in all the women -in Maddy, in Tyler's daughter with the removal of her reproductive organs, in Miss Fitt, the dried, shriveled spinster and in the deaths of the three little girls-Minnie, the little girl in Maddy's story, whose illness was diagnosed as" due to never having been born",(Beckett,1986p.169) and the little child who fell off the train. Even the leaves are rotten during the month of June and the laburnums look faded, losing all their tassels. The sight of the sterile landscape raises in Maddy's mind a doubt with regard to the validity of creation. Her doubt expresses itself in a sudden query, which is the climactic culmination of the discreative process that had set in with the death of the children and the removal of sexual organs. Maddy asks:

Can hinnies procreate?...You know, hinnies or jinnies, aren't they barren or sterile, or whatever it procreate?...Yes it was hinny he rode into Jerusalem or wherever it was on a hinny.(Pause.) That must mean something.(Beckett,1986,pp.196-197)

But Maddy lacks courage to accept a barren world. She looks for some form of escape.Even death seems to her a blessed release. She does not have the stark vision of her blind husband, Dan, with regard to the timelessness of timebound sequences confined between birth and death. She knows that everything falls and she has not learnt to take the fall with Dan's stoicism and passivity. More than once she gives expression to the inevitability of the fall, as she mutters to herself "The best of the day is over. Soon the rain will begin to fall and go on falling ... then the setting sun will shine an instant, then sink, behind the hills."(p.p.181-182). In this world of alienation and instant deaths, she observes the golden drizzle and in it she finds a shattering consolation. Had Minnie lived, she would also been running down like the rest. Maddy does acknowledge this painful fact:" In her forties now she'd be, I don't know, fifty, girding up her lovely little loins, getting ready for the change.'(Beckett, 1986, p.176)
Like her predecessors Vladimir and Clov, she gets her flashes of insight to give up hope and defy suffering, but she does not have the strength that Dan displays in the face of life's mockery of human endeavor. Maddy withdraws her stance of defiance to pick up the thread of her journey, soliciting help from Mr. Tyler, Slocum and Barrel and seeking recognition from the barely alive Miss Fitt. But her awareness of the futility of human strivings gives her insight enough to comment with a sigh, "Christ what a planet!"(Beckett, 1986, p.183) She relapses into hopes, fondly expecting emotional sustenance from Rooney. She reminds him of his birthday and desires that he stays nice and tender towards her as of old. With naïve cheer and facile optimism, she affirms that they" shall press on and never pause, never pause till we come safe to haven."(Beckett, 1986, p.194)

Dan attempts through unkindness and cruelty to school her into an acceptance of suffering without holding to illusory hopes of escaping it. But she can neither cast off her illusions nor can she ignore the decay and disintegration around her. She continues her trips and seeks human warmth by asking Dan to put his arm around her and be nice to her.

Maddy's dragging to and from the station is symbolic of the life -long journey men and women drag through with no visible end in sight. All That Fall begins and ends with the sound of music from Death and the Maiden and as the curtain rings down, all that is heard are the dragging feet of Dan and Maddy on their onward journey, occasionally halting to the rise and fall of the tempest of wind and rain. The end is circuitously brought to the beginning of the play, but the journey is not yet over. It plods on slowly and drearily. All that one notices is that the journey has taken time and time has had its toll in the squashing of the hen, the death of the child who fell off the train and in the loss of the tassels of the lovely laburnums. Dan has brought Maddy close to his concept of alienation as she joins him in his cynical, bitter laugher at the end of the play. Maddy's brief "No" to "Nothingness" heralds on Beckettian stage the arrival of Winnie who is determined to turn a cheerful face on suffering and move on through the dreary journey of life, halting, taking but never falling.

Beckett's cerebral drama uses grotesque devices to indicate the irrationality and absurdity of life. However exaggerated and strange his grotesque world may be, it is rotted in the concrete and the rationally perceivable world. His plays works within "the plane of the feasible" to evoke the frightening perception of absurdity. While his men and women are low life masks of Everyman, Beckett's grotesque plays go beyond the physical ugliness of decay and depletion to present the horrifying aspects of existence. Beckett exposes Man alone in the mud, to concretize on the stage what he sees as the tragic condition of mankind.

\section{REFERENCES}

Ackerley, C. \& Gontarski, S. (2004).The Grove Companion to Samuel Beckett. Grove Press. 
Alpaugh, D. (1966). The Symbolic Structure of Samuel Beckett's All That Fall. Modern Drama,9,3.

Beckett,S.(1986). The Complete Dramatic Works. London and Boston: Faber \&Faber.

Ben-zvi,L.(2011). Beckett and Disgust: The Body as "Laughing Matter". Modernism/modernity, 18, 4.

Campbell,J.(2005).The Entrapment of The Female Body in Beckett's Plays in Relation to Jung's Third Tavistock Lecture. Samuel Beckett today/Aujourd'hui.Vlo.15.
Driver F. Tom, (1961). Beckett by the Madeline. Columbia University Forum. IV

McDonald,Ronan.(2006).The Cambridge Introduction to Samuel Beckett.Cambridge University Press.

Merciier,V.(1979).Beckett/Beckett. London: Oxford University Press.

Van Laan, Tomas F.(1985). All That Fall "as Play for Radio". Modern Drama,28,1. 